\title{
Falia's Ke-kaghati-an in Muna Speech Community From the Ecolinguistic Perspective
}

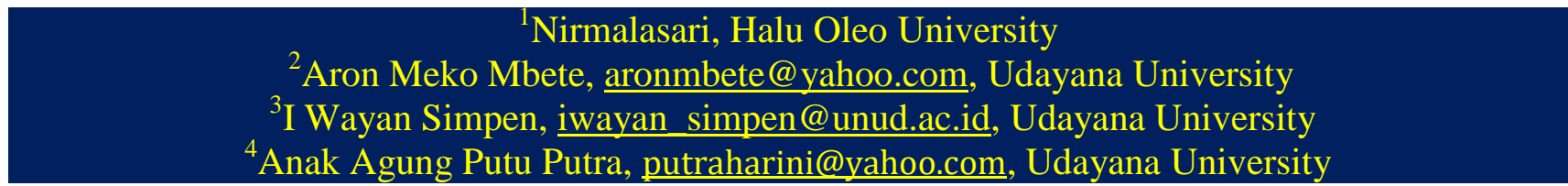

*Corresponding Author: nirsidu@gmail.com

Received Date: 10-10-2018 Accepted Date: 15-10-2018 Published Date: 31.-07.-2019

Abstract - This paper explained falia 'taboo' in kaghati in the Muna Speech Community (MSC) from the ecolinguistic perspective. The kite 'kaghati' is one type of the traditional games and a tribal cultural product in MSC which still exists and remains maintained. The forms of interaction, interrelation, and the interdependence in MSC with the natural and socio-cultural environments are recorded in falia's ke-kaghati-an. The problem in this paper is to answer the question what expression in falia's ke-kaghati-an is used to express environment in MSC. The purpose of this paper is to describe and analyze the falia expressions found in ke-kaghati-an's environment. This research is classified as a qualitative descriptive study as it describes the phenomena of falia expressions and environmental knowledge, especially the ones currently used in ke-kaghati-an's environment, and the source of natural data as a manifestation of the Muna's socio-cultural-ecological life.

Falia's ke-kaghati-an is such a magical expression of magical value that MSC, especially the kaghati maker, feels afraid of breaking it.The expression of falia's ke-kaghati-an teaches the belief in God, gratitude, balance of life, discipline, justice, honesty, orderliness, beauty, tolerance, and mutual respect. Falia is one way in which MSC shows their adherence to the local wisdom values, especially with regard to the environmental conservation that has been inherited from the ancestors since a long time ago. Conservation of the wealth of the expression of falia in MSC is very important, for both the sustainability of the Muna language and the conservation of kaghati with its traditions and culture, which is preserved in the meaning and cultural values of the past heritage as part of itspersonal identity, especially for the younger generation.

Keywords: falia's expression, ke-kaghati-an, Muna speech community, ecolinguistic perspective.

Language is not only used as a means of communication (Mbete, 2008), but it also contains a cultural vision, namely recording, maintaining, and transmitting collective concepts, historical, philosophical, socio-cultural, and ecological values of a society. Language is a symbol and element of culture that is inherent in human life. In socio-culture, language is a real component of culture and can also directly distinguish one ethnic community from another ethnic community. As a social reality, language is a phenomenon used by its community to communicate and interact within the situational and cultural context in an environment. 
Muna language (ML) describes the reality of the environment and the reality of the speech community. ML as a communication tool,unifying tool, and the identifier of the ML speech community also has ideological, sociological and biological functions. ML functions touncover everything in the form of ideas or mindset of its speech community. In addition, ML also functions to record everything that is outside the speech community its self, namely the environment. Thus, ML functions to uncover good mindset and becomes a means of conserving the environment, both natural environment and socio-cultural environment. The existence of Munaspeech community (MSC) is influenced by the interaction between individuals in MSC and the natural and socio-cultural environments. One form of the interaction, interrelation, and the interdependence of social relations between ML and the natural environment and socio-cultural environment is recorded in falia's kekaghati-an.

La Taena (2014: 91) said that falia 'taboo' is a social prohibition or prohibition in community life that should not be violated by Muna Ethnic people, either in action or speech. Marafad and La Niampe (2017) revealed that the falia's expression is an ancestral cultural heritage that has the educational value towards the children's character which contains the values of sincerity, honesty, fairness, discipline, obedience, respect for others, tolerance, belief and faith. Apart from these values, there are also magical values; the child tends to follow what parents convey through themessage containedin the falia's expression.

Kaghati or kite has religious magical meaning for MSC, which is believed to be an "umbrella" that will guard its owner from the sun when he dies later.When the owner dies, he "leaves" by holding on to the kaghati's rope or called ghurame "rope made of pineapple leaf fiber" and sheltered under kaghati.In relationwith that belief, MSC is paying attention to and obey all the requirements applied in kaghati, especially bythe kite makers or referred to as pande ghati. It starts from the preparation of materials, the spinning process of the rope, the kaghati making process, thekaghati playing manner, and to the performance of the ritualkaghati. This is closely related to the expressions of falia or taboo that should not be violated because there will be mystical sanctions felt by the makers of kaghati, even MSC itself. Falia is one of the ways used by MSC to show thatit adheres to the local wisdom values, especially in relation to the environmental conservation inherited by the ancestors since a long time ago. 
Based on the explanation above, the problem in this paper is what expressions in falia's ke-kaghati-an are used to express environment in MSC. The purpose of this paper is to describe and analyze the falia expressions found in ke-kaghati-an's environment.

\section{Theoretical Framework}

Ecolinguistic theory is used in this research. Ecolinguistic is a theory that connects linguistics and ecology. Ecology in linguistics has a very important role. The ecological linguistics is important, especially if it is related tothe language sustainability. Because there is an assumption that language death results from the environmental degradation. Departing from these philosophical thoughts, environment has been one of the important studies in linguistics. Ecolinguistics is an "umbrella term" which covers a rich diversity of theoretical approaches (Fill, 2000).

Ecology of language in ecolinguistics refers to two things, namely (1) physical or physical environment, and (2) social environment. The physical environment includes geographical characters such as the topography of an area (beaches, valleys, plains, highland or mountains), climate, rainfall levels, and basic human economic needs which include flora, fauna, and mineral resources that can support human life. The social environment encompasses various community forceswhich shape the way of life andthe way of thinking of each individual.The important things in this social power are religion, ethics, political organization, and art. In relation to the linguistic environment, Bang \& Door (in Bundsgaard and Steffensen, 2000:10) describe the linguistic environment with the following Logical Dimension Model.

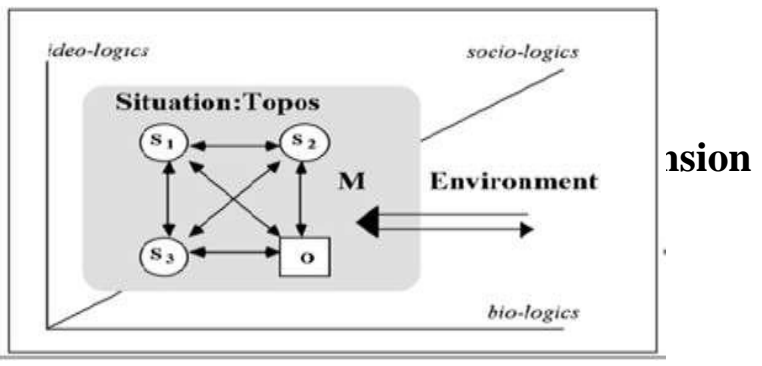

Dialogical Dimension Model

The dialogical model is dialectical. This is indicated by the dialectical arrows, which symbolize the relationships between the phenomena (participants, objects and media) in thesituation, 
and between the environment and the situation, and show that these relationships areunequal. In the model, the direction of each dialectical arrow does not only illustrate that the contexts of communication dominate and constitute the situation and the dialogue, but also illustrate that thesituational dialogue influences the context. The model also illustrates the principles ofcomplexity in every dialogue. Traditionally, for example, in conversation analysis, and in critical discourse analysis, a dialogue is defined as an exchange of meaning between two or more participants. Our conception ofdialogue differs from this conception as we define that a dialogue as takes place among at leastthree persons. The third subject, S3, might be physically present in some situations and absentin others, but no communication occurs between two subjects only. Bang, Døør, Steffensen\&Nash point out that: "The S3 position might be occupied by a person who is superior, equal withor in an inferior position in relation to S1 and/or S2 or both of them or none of them". The S3 might also be more anonymous or generalized, for example, our social conventions and thesubjects who represent them. The anonymous S3is often linguistically expressed by means of the zero deictic "you" or the plural "we" and a demanding modality like "must" or "should".

The three dimensionalities of the social praxis can readily be seen as Bang \& Door's theoretical frame or basis of understanding and explaining the environmental constitution of language. The three dimensions are dialectically determined and determining. The three logical dimensions are interrelated with historical and dynamic systems of recurrent invariances, patterns and tendencies (Bang \& Door, 2000). The ideo-logical dimension is about our individual and collective mental, cognitive, ideological and psychic systems. The socio-logical dimension is about the ways we organize our interrelations in order to maintain a collectivity of individuals, whether these individuals love each other (eg. in a family and among friends), know each other (eg. in political systems, like a region, a state). The bio-logical dimension is about our biological collectivity and our coexistence with other species (animals, plants, soil, oceans, microorganisms, etc).

\section{Research Methods}

This research is classified as qualitative descriptive research. The reserach was conducted in Muna, Southeast Sulawesi, in two sub-districts namely Lohia, Liang Kobori village; and Watopute, Wali village. It is believed that the physical and social environment in these locations holds a diversity and ecological richness (biotic and abiotic) which is transmitted through various lexicons of Muna language related to kaghati's culture.In collecting data, direct observation and in- 
depth interviews (Black and Champion, 1992: 308-310) were conducted. Directed and focused interviews were used to obtain the data on falia's expressions through the information given by the informants in Muna language that is related to the living context of the kaghati environment of Muna Speech Community.

Personal experience methods (Denzin and Lincoln, 2009: 497) also contributed to the data acquisition. The informants' personal experiences reflect the idea, the meaning of the individual experience which is in this reserach related to the ke-kaghati-an environment. The fact that each individual has its own personal experience means that each individual has a reflection of the idea of ke-kaghati-an environment so that the meaning of each experience is different from one another.The activities in data analysis included data reduction, data display, and conclusion.

\section{Dsicussion}

A long time ago, MSC generally eduacated children using the falia or taboo's expression, advice, and religious advice. Character education through falia's expression can be done by anyone, both fellow children, adolescents with children, adults with teenagers, teenagers with teenagers, or parents with parents. In relation to ke-kaghati-an, MSC considers kaghati a unique type of game and is different from the other types of games. Kaghati has a relationship with the mystic, so the game of kaghati is not only played by people. The things that need to be prepared range from the collection of materials to the ritual process, during which the kaghati maker or pande ghati must obey all the requirements applied in all kaghati games. If the procedure or rule is violated, then the sanctions will be felt by both the kaghati maker and the people who violate it. $O$ falia is a magical expression that has magical value; therefore, people are afraid of breaking it. The interaction, interrelation and interdependence of the environment with social life of the speech communitycreates expressions related to ke-kaghati-an as a sign that the environment greatly influences the cognition of its speakers. Here are the expressions of falia 'tabu' which are closely related to ke-kaghati-an.

1) $O$ falia kaindere -no kaghati raa-buku

Art.pemali rangka tengah Pos layang-layang dua buku

'Pemali rangka bambu tengahnya berbuku dua'

"Taboo, the middle of bamboo's frame has two knuckles" 
The falia above means that wulu or reed used as a middle frame in kaghati should not have two knuckles or more, one knuckle only. If there are two knuckles, then kaghati cannot hover well in the sky or called mina naentaga. If one frame contains two junkles, the balance is lost because the middle frame becomes heavier than the other frames.This expression teaches that MSC should always create balance and harmony by not being excessiveand lacking in all aspects of life in the universe, meaning that it does not act destructively only to fulfill life satisfaction but it should put things in their places and in accordance with their portions. This falia 'taboo' emphasizes more on balance in life so as not to be one sided and it will create a peace of life towards happiness among ideological, sociological, and biological dimensions.

\section{2) $O$ falia fitu-alo-mo no-tiri maka mina dae-basa-ane dhoa}

Art. Pemali tujuh malam Suf. 3T bermalam Konj.tidak 1J baca Konj. doa 'Pemali tidak diritualkan setelah kaghati tujuh malam bermalam di angkasa'

"Taboo, kaghati is not ritualized after seven nights in the sky"

The falia above means that kaghatiwhich has been seven nights in sky must have a ritual prayer. If ignored, kaghatiwould not be a protective tool (umbrella) from the heat of the sun in afterlife. This falia describes strong belief in things which aresupernatural; belief in the existence of life after death. Besides, MSC believes that there will be a disaster 'balaa' felt or affected by those who ignore the ritual. This falia teaches to be always grateful to God for the blessing that has been given and competing in goodness because what is done in the world, good or bad towards fellow beings and the environment, the reward will be acquired in the hereafter.

\section{3) O falia do- fo- fo- tingkulu roo-kolope-no}

Art. pemali Pref. Pref. Pref. balik daun gadung Pos.

'Pemali memasang terbalik daun gadung'

"Taboo, put gadung leaves in upside down position"

It is intended that the kaghati maker must be so careful when putting gadung leaves that the position will not be upside down. If that happens, kaghati will spin in the sky, not hovering calmly. Therefore, putting gadung leaves on the kaghati's net should be regular, no mazy, same head direction so that it looks organized and beautiful. Thus, the falia'taboo' shows that kaghati lovers pay attention to regularity and beauty so that harmonious relationships are cerated in kaghati and between kaghati itself with the maker and audience.

4) $O$ falia de-ene ko- kaghati -no

Art.pemali 3J pungut Pref. layang-layang Pos. 'pemali memungut kaghati orang lain' 
"Taboo, picking up other people's kaghati"

The falia is intended notto get sin or will get tortured by God. This falia illustrates the belief of MSC that taking someone else's goods is forbidden, and that is sin. Sinful acts for the Muna ethnic people are deeds that are despicable and must be avoided. This teaching is in line with the teachings of the Muna ethnic which is related to the ritual of coronation 'katoba' for a child when he enteres adolescence. In the implementation of the ritual it is said that even as large as zarra the goods or property of other people should not be taken at all without the permission of the owner. This falia teaches MSC to respect other people and not take things that are not their rights or do things that can harm others or their environment.

\section{5) O falia no-po- loli roo kolope moghane bhe robhine}

Art. pemali 3T Pref tukar daun gadung jantan Konj. betina

'pemali daun gadung dipasang bertukar'

"Taboo, gadung leaf is exchanged"

The meaning of this falia is that kaghati will not spin in the sky or in Muna language it is referred to asneuleane. This falia illustrates that MSC likes to put things where they should be. It also describes discipline, good justice for ourselves by placing ourselves in a good and also the right place, fair to others, and fair to other living beings (animals and plants), and the environment. Therefore, MSC can maintain the harmony of its life, especially its relationship with environmental sustainability, create a harmonious and safe life, have a high tolerance, and be responsive to environmental problems.

\section{Novelties}

This research has two novelties, as follows. First, theoretically,it can be explained that the use of the natural environment in ecological language is closely related to the traditional game of MSC, namely the kaghati kolope whose entire material is directly obtained from the natural environment. The language and environment (physical and social environment) are interrelated as the concept of ecolinguistic theory. The same thing is also emphasized in Bang \& Doors dialectical theory (in Lindo and Bundesgaard, ed., 2000) in which it is proposed that language is part of a social activity that contains social praxis, namely a concept that refers to all actions, creativity, community 
behavior, both fellow community members (social environment) and the natural environment.The application of tridimension to ecolinguistic studies, namely the ideological dimension, the biological dimension, and the sociological dimension are closely related to the Muna Speech Community's life. Second, empirically, the falia's expressions in ke-kaghati-an are closely related to the Muna Speech Community and its environment, physically and socially. Falia's ke-kaghati-an is carried out based on customs and habits of MSC, e.g. putting roo kolope 'gadung leaf' on kaghati's wall should not be done carelessly and becomes falia when it is violated, kaghati being unable to fly perfectly.

\section{Clossing}

Based on the explanation in the discussion above it can be concluded that falia's expression in ke-kaghati-an's environmentis an ethnic wealth in the form of local wisdom of ancestral heritage and regional peculiarities that need to be explored and empowered for the sake of the environmental sustainability. Falia's expression in ke-kaghati-an teaches the belief in God, gratitude, balance of life, discipline, justice, honesty, orderliness, beauty, tolerance, and mutual respect.Conservation of the wealth of the expression of falia in MSC is very important, both for the sustainability of the Muna language and for the conservation of kaghati with its traditions and culture, which is preserved in the meaning and cultural values of the past heritage as part of its personal identity, especially for the younger generation.

\section{References}

ADISAPUTERA, Abdurahman et al. SUSTAINABILITY OF LANGKAT MALAY LANGUAGE A STUDY OF COMMUNITY OF YOUNG PEOPLE IN STABAT, LANGKAT REGENCY. e-Journal of Linguistics, [S.1.], nov. 2012. ISSN 2442-7586. Available at: https://ojs.unud.ac.id/index.php/eol/article/view/3540>.

Date accessed: 09 oct. 2018.

Bang, J and Døør, J. 2000. Ecology, Ethics \& Communication, Dialectical Ecolinguistics: Edited by: Anna VibekeLindø and JeppeBundsgaard, (53-84). University of Odense, Denmark.

Berg, Rene van Den dan La Ode Sidu Marafad. 2013. Kamus Muna-Indonesia. Cetakan Pertama, Yogyakarta: PustakaPuitika.

Black, James A. Dean J. Champion1992.MetodedanMasalahPenelitianSosial. Penerjemah: E. Koeswara, DiraSalam, AlfinRushendi. Bandung: Eresco. 
Bundsgaard, J and Steffensen, S. 2000. The Dialectics of Ecological Morphology or the Morphology of Dialects. Dialectical Ecolinguistics: Edited by: Anna VibekeLind $\varnothing$ and JeppeBundsgaard, (8-36). University of Odense, Denmark.

Daeng, Hans J. 2000. Manusia, Kebudayaan, dan Lingkungan. Yogyakarta: Pustaka Pelajar.

Fill, A and Peter Mühlhaüsler (eds). 2001. The Ecolinguistics Reader: Language, Ecology, and Environment. London and New York: Continuum.

Halliday, M.A.K. 2001. New ways of Meaning: The Challenge to Applied Linguistics, The Ecolinguistic Reader: Language, Ecology, and Environment. Edited by Alwin Fill and Peter Mühlhaüsler (175-202). New York: Continuum.

Haugen, Einar. 1972. The Ecology of Language. Stanford, CA: Stanford University Press.

Lindø, Anna Vibeke and Jeppe Bundsgaard (eds). 2000. Dialectical Ecolinguistics: Three Essays for the Symposium 30 years of Language and Ecology. Odense: University of Odense.

Marafad, La Ode Sidu dan La Niampe. 2017. Model Buku Ajar Ungkapan Falia sebagai Materi Pendidikan Karakter Siswa SD di Kabupaten Muna, Sulawesi Tenggara. Yogyakarta: Penerbit Pustaka Puitika.

Mbete, Aron Meko. 2002. "Ungkapan-Ungkapan dalam Bahasa Lio dan Fungsinya dalam Melestarikan Lingkungan.” Linguistika. Volume 9, No. 17. Denpasar.

Mbete, Aron Meko. 2009. "Refleksi Ringan tentang Problematika Keetnikan dan Kebahasaan dalam Perspektif Ekolinguistik.” Makalah Seminar Budaya Etnik III. Medan: USU.

Odum, Eugene P. 1996. Dasar-Dasar Ekologi. Yogyakarta: Gadjah Mada University Press.

RAMBUT, Kanisius et al. ECOLINGUISTIC PERSPECTIVE OF KERAPINGAN CULTURE. e-Journal of Linguistics, [S.1.], p. 40--53, oct. 2015. ISSN 2442-7586. Available at: <https://ojs.unud.ac.id/index.php/eol/article/view/16129>. Date accessed: 09 oct. 2018.

Sapir, Edward. 1912. Language and Environment. American Anthropologist New Series, Vol. 14, No. 2 (Apr-Jun, 1912), pp. 226-242.

\section{Acknowledgements}

Thanks are expressed and a word of appreciation should go to the board of examiners: Prof. Dr. Drs. Ida Bagus Putra Yadnya, M.A., Prof. Dr. I Ketut Darma Laksana, M.Hum., Dr. Ni Made Dhanawaty, M.S., Dr. Ni Made Suryati, M. Hum, and Dr. La Ino, S.Pd., M.Hum, for their critical comments and suggestions for the improvement of this paper. 